
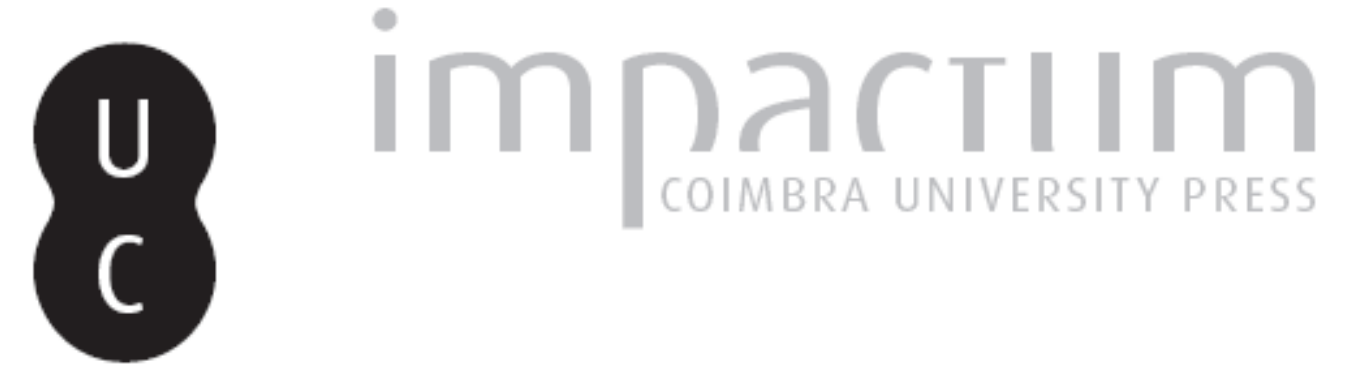

\title{
O papel das rainhas viúvas na consolidação do reino: os testamentos dos primeiros reis de Portugal
}

Autor(es): $\quad$ Marques, Maria Alegria Fernandes

Publicado por: Faculdade de Letras da Universidade de Coimbra, Instituto de História

URL

persistente:

URI:http://hdl.handle.net/10316.2/33428

DOI: $\quad$ DOI:http://dx.doi.org/10.14195/0870-4147_44_4

Accessed : $\quad$ 26-Apr-2023 11:28:29

A navegação consulta e descarregamento dos títulos inseridos nas Bibliotecas Digitais UC Digitalis, UC Pombalina e UC Impactum, pressupõem a aceitação plena e sem reservas dos Termos e Condições de Uso destas Bibliotecas Digitais, disponíveis em https://digitalis.uc.pt/pt-pt/termos.

Conforme exposto nos referidos Termos e Condições de Uso, o descarregamento de títulos de acesso restrito requer uma licença válida de autorização devendo o utilizador aceder ao(s) documento(s) a partir de um endereço de IP da instituição detentora da supramencionada licença.

Ao utilizador é apenas permitido o descarregamento para uso pessoal, pelo que o emprego do(s) título(s) descarregado(s) para outro fim, designadamente comercial, carece de autorização do respetivo autor ou editor da obra.

Na medida em que todas as obras da UC Digitalis se encontram protegidas pelo Código do Direito de Autor e Direitos Conexos e demais legislação aplicável, toda a cópia, parcial ou total, deste documento, nos casos em que é legalmente admitida, deverá conter ou fazer-se acompanhar por este aviso.

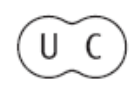




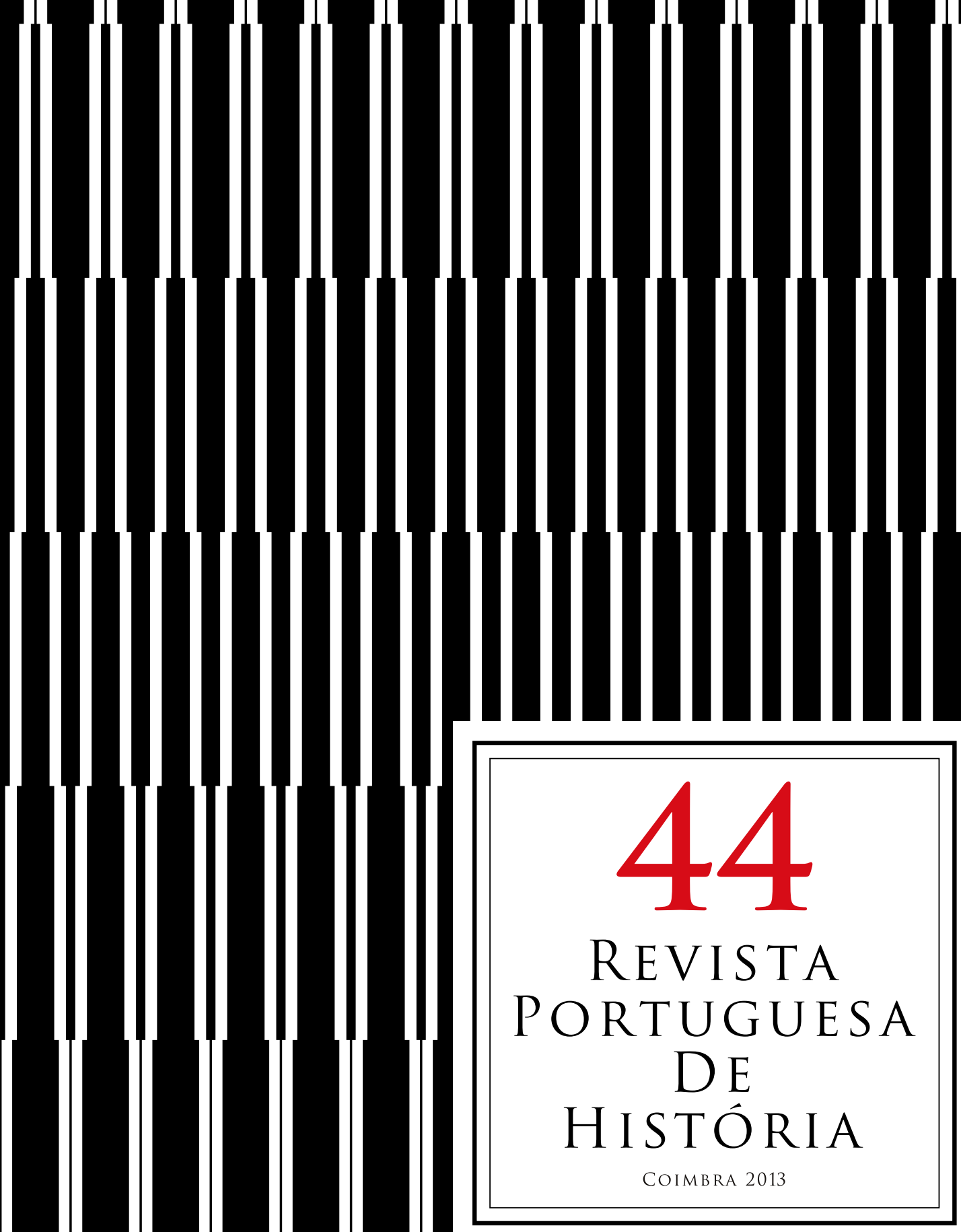




\title{
O papel das rainhas viúvas na consolidação do reino (Os testamentos dos primeiros reis de Portugal)
}

\author{
Maria Alegria Fernandes Marques \\ Centro de História da Sociedade e da Cultura \\ Faculdade de Letras - Universidade de Coimbra \\ mfm@fl.uc.pt
}

\section{Resumo:}

Considerando a família real como um dos esteios sobre os quais se erigiu o reino de Portugal, com base nos testamentos dos primeiros reis de Portugal que os outorgaram na sua condição de governantes e homens casados procura-se lançar alguma luz sobre o entendimento que faziam do papel de suas mulheres, mormente no caso de elas lhes sobreviverem enquanto suas consortes e rainhas de Portugal.

\section{Palavras chave:}

Reino de Portugal; Idade Média; Testamentos régios; Rainhas viúvas; Regência.

\section{Abstract:}

Considering the royal family as one the pillars on which was erected the kingdom of Portugal, based on the testaments of portuguese first kings we try to understand the role of their women, especially if they survive them while their consorts and queens of Portugal.

Keywords:

Kingdom of Portugal; Middle Ages; Royal testaments; Widowed queens; Regency. 
1. São conhecidos os pilares sobre os quais assentou a criação do reino de Portugal: um chefe, um território e as suas gentes, uma família, uma Igreja. Todavia, era certo que nenhum deles valia por si, antes achava o seu valor na interligação que lograsse com os restantes e na dinâmica que todos conseguissem face à matriz de onde havia de destacar-se a novel formação política. Em conjunto, tais elementos, tão díspares e tão próximos, faziam parte de um sistema em construção, com vista a um fim donde viria significado ao todo que compunham.

Mas não bastava a acção de criar uma nova entidade autónoma. De par, e mais importante até do que ela, vinha a sua consolidação. Do lugar e dos companheiros do chefe, à afirmação de um território sobre o qual se estendia a sua soberania, a uma família que se arrogasse a patrimonialização do reino, a uma Igreja que sentisse os problemas da terra como seus e lhe buscasse resposta como parte sua, tudo era objectivo a alcançar. Todas elas eram promessas a cumprir ao fim último de um desígnio que se volvia de todos, nos laços que cada um soubesse entender e nas teias que ousasse lançar.

E é sabido que o tempo em que surgiu o reino de Portugal era um tempo grande de construção, tanto maior se pensado em termos de Península Hispânica; o processo da Reconquista possibilitava a acção; e os homens, cristãos ou muçulmanos, não se faziam rogados. Embora, por este prisma e no nosso caso, o aspecto mais óbvio fosse o da construção do território do reino, não deixa de ser verdade como essa acção se vivia a muitos outros níveis. A sociedade e a economia recompunham-se consoante a conjuntura, a Igreja desenhava e consolidava os seus espaços, os poderes locais conformavam-se numa rede de múltiplos e mais ou menos coesos ou momentâneos interesses.

Dentre os pilares que citámos no início, a família do rei afigura-se como um elemento fundamental. Nela, o chefe se realizava como homem, que também era e, acima de tudo, achava a continuidade no poder, garantia, nela, da condição de chefia. Em tempos de monarquias patrimoniais, essa circunstância era penhor da própria continuidade do reino enquanto entidade autónoma.

Mas a família do rei era tão vulnerável como outra qualquer. Por isso, não admira as diligências que envolviam a escolha da mulher do rei e os cuidados que os reis lhe devotavam quando procediam à lavra dos seus testamentos, ou, ao invés, algumas controvérsias a propósito de momentos de regência ou de tutela do reino.

2. É nesta ampla moldura que se inscreve o tema que nos propusemos tratar. O papel das rainhas e os testamentos régios assumiam-se como importantes instrumentos de poder e de consolidação do reino, num tempo de monarquias hereditárias e patrimoniais. 
O âmbito cronológico em que nos situamos é o do primeiro século do reino de Portugal, isto é, procuraremos apresentar o problema nos três primeiros reinados da história portuguesa, pese, embora, bem entendermos como ele é passível de ser encarado num âmbito cronológico bem mais dilatado.

\subsection{Afonso Henriques}

Somos de opinião de que o problema, tal qual o pretendemos aqui equacionar, não se colocou relativamente ao primeiro rei de Portugal. O rei ficou viúvo após uma escassa dúzia de anos de matrimónio e muito antes de ter mandado redigir qualquer manda ou testamento, que se conheça, o que inviabiliza qualquer interpretação acerca de um papel que a rainha pudesse protagonizar após a sua morte e, sobretudo, do pensamento do rei sobre a matéria, se o tinha. Por outra via,é de sublinhar que nenhum dos seus testamentos - entendam-se deste modo aqueles tradicionalmente assim considerados ${ }^{1}$, ou aceite-se esta classificação apenas para o que se afigura ser o verdadeiro testamento, embora se apresente sem data (mas que há-de ser posterior ao de Fevereiro de 1179)² -, se ocupa do governo do reino, isto é, da sua sucessão, sinal de que essa matéria não era problema ${ }^{3}$.

Desta forma, interessa-nos equacionar os testamentos dos reis D. Sancho I e de D. Afonso II à luz da problemática proposta.

\subsection{Sancho I}

Se é sabido que o rei D. Sancho I mandou lavrar dois testamentos, em conformidade com uma das premissas de que partimos apenas nos importa o primeiro, já que, na data do segundo, o rei era viúvo, de alguns anos.

1 Documentos medievais portugueses: Documentos régios, vol. 1/I: Documentos dos Condes Portucalenses e de D. Afonso Henriques. A D. 1095-1185. Lisboa: Academia Portuguesa da História, 1958, p. 430-431 e 436, n. ${ }^{\text {os }} 330$ e 334, respectivamente (doravante, DR.).

2 Em justificação do que afirmamos no texto, ver Maria Alegria Marques e João Soalheiro, A corte dos primeiros reis de Portugal. D. Afonso Henriques. D. Sancho I. D. Afonso II. Gijón: ed. Trea, 2008, p. 247-251. Também José Mattoso, D. Afonso Henriques. Lisboa: Círculo de Leitores, 2006, p. 260, vê no documento de Fevereiro de 1179 mais uma contribuição à causa do reconhecimento da independência de Portugal pela Santa Sé que um verdadeiro testamento.

3 Sobre a posição do infante D. Sancho, herdeiro e sucessor do primeiro rei de Portugal, ver Maria Alegria Marques e João Soalheiro, ob. cit., p. 53-54 e 253. 
O primeiro testamento do rei $\mathrm{D}$. Sancho I é um documento não datado ${ }^{4}$. Porém, tradicionalmente, os autores situam-no pelo início do ano de 1188, talvez pelo mês de Março. Na obra que dedicou a esse rei, Maria João Branco propôs que ele tenha sido redigido "mais tarde no ano de 1188 ou mesmo já em 1189"5, data esta que bem se adequa à mais importante campanha militar levada a cabo no reinado do segundo rei de Portugal. Trata-se, como é sabido, da conquista de Silves ${ }^{6}$, expressão portuguesa do clamor provocado na Cristandade pela tomada de Jerusalém por Saladino, em 1187, que faria rumar ao Oriente, novas armadas de gentes do Norte, aportando, necessariamente, em Portugal (Lisboa), e prontas ao auxílio na luta contra os muçulmanos da Espanha. Igualmente esse âmbito cronológico colhe significado em vista do tempo do falecimento (inesperado) de Fernando II de Leão ${ }^{7}$, com a oportunidade de reequacionamento do quadro de relações na Hispânia, entre Portugal e Castela, enquanto se desejavam menos hostis para Portugal as que se haviam de ter com o novo rei de Leão.

Com efeito, a leitura do documento faz afastar qualquer problema pessoal do rei, para colocar a sua génese em circunstâncias bem diversas, de que as de carácter militar são as que melhor se lhe coadunam. Não só o rei considerava a sua morte, como temia a sua ausência ou a ocorrência de qualquer infortúnio que lhe impedisse a liberdade de seu corpo. Seria, pois, algo de muito grave, cuja melhor caracterização se encontra em tarefa de índole militar. Ora, a análise da conjuntura do tempo em que se inscreve aponta para a preparação de uma campanha de envergadura que, pelo seu ignorado desfecho ou presumida delonga, causava fortes apreensões ao rei e lhe requeria cuidados acrescidos relativamente ao reino (e à sua família). Ainda que seja possível desenhar-se, ao tempo, uma qualquer campanha, a levar a cabo por si próprio, talvez em acção dirigida a Serpa ou outra praça das redondezas, com o objectivo último

4 Rui de Azevedo, P. Avelino de Jesus da Costa e Marcelino Rodrigues Pereira, Documentos de D. Sancho I (1174-1211), Coimbra, Instituto Nacional de Investigação Científica, Centro de História da Sociedade e da Cultura da Universidade de Coimbra, 1979, p. 47-48, doc. n. ${ }^{\circ} 30$.

5 D. Sancho I. O filho do Fundador. Lisboa: Círculo de Leitores, 2005, p. 124.

6 Ainda que esse novo domínio fosse efémero para o rei de Portugal, mesmo assim foi-lhe altamente vantajoso: por um lado permitiu-lhe o alargamento do seu título como "rei de Portugal e do Algarve" ou "rei de Portugal, de Silves e do Algarve", bem como, e não menos importante, a obtenção de uma nova bula Manifestis probatum (7 de Maio de 1190), endereçada ao rei Sancho I e aos seus "heredibus", prova da afirmação da família reinante portuguesa. Sobre este segundo aspecto, ver Maria Alegria Fernandes Marques, A bula Manifestis Probatum. Ecos, textos e contextos, in Poder espiritual. Poder temporal. As relações Igreja-Estado no tempo da monarquia (1179-1909). Actas do Colóquio. Lisboa: Academia Portuguesa da História, 2009, p. $87-123$.

7 Benavente, 22 de Janeiro de 1188. 
de Sevilha, ou em conjunto com Afonso VIII de Castela, dirigida também para essa região, o aparecimento de um grupo de cruzados, nas circunstâncias referidas, acabou por fazer desviá-la para Silves.

Além destes problemas, misto de princípios e de circunstâncias próprios, a leitura do documento deixa como provável algum clima de mal-estar interno, vivido por então, mas que o rei teve capacidade de controlar. Com efeito, a referência aos haveres de Guimarães que estavam em posse dos priores (um deles, por certo o da colegiada), de um certo Vilão ${ }^{8}$ e de Gomes de Rochela, e que haviam sido dos "militibus qui mihi non servierunt", isto é, dos cavaleiros que o não tinham servido, bem pode significar um clima de perturbação que, tudo indica, terá envolvido os tenentes dos castelos de Vermoim, Penafiel, Benviver e Lanhoso, sem termos como saber se estes seriam a totalidade dos faltosos e que faltas constituíram esse "desserviço".

Indício de algum circunstancialismo próprio que rodeou a feitura do primeiro testamento do rei D. Sancho I parece-nos estar patente ainda num pormenor formal deste documento, que é o reduzido número de testemunhas do acto e a sua qualidade. Nesse momento importante para o homem e para o rei, apenas o acompanharam o bispo de Viseu, D. João, o prior de Santa Cruz de Coimbra, Pedro $^{10}$, e o abade de Alcobaça, Martinho ${ }^{11}$, o seu irmão Pedro Afonso, ao tempo alferes régio, Afonso Ermiges, João Fernandes, Álvaro Martins, alcaide de Coimbra, e Julião, notário do rei.

Indique-se ainda que o primeiro testamento sanchino surgia, assim, quando o rei rondava os 34 anos e o seu reinado ia pouco além do início do seu terceiro ano, embora a sua experiência de governo o ultrapassasse em muito.

A esta circunstância deve acrescentar-se que D. Sancho I estava casado desde 1174, com Dulce de Aragão, de cuja união havia um total de cinco filhos, três varões e duas raparigas ${ }^{12}$, mas todos de menor idade.

${ }^{8}$ O qual a chancelaria de seu pai garante ter sido vicarius (régio) na região vimaranense.

9 Maria Alegria Marques e João Soalheiro, ob. cit., p. 69-70.

${ }^{10}$ Saul Gomes, In limine conscriptionis. Documentos, chancelaria e cultura no Mosteiro de Santa Cruz de Coimbra. Séculos XII a XIV. Coimbra: Centro de História da Sociedade e da Cultura, 2007, p. 590, identifica-o como Pedro Alfarde.

${ }^{11}$ Saul Gomes, "Revisitação a um velho tema: a fundação do mosteiro de Alcobaça", In Cister. Espaços, Territórios, Paisagens. Colóquio Internacional. 16-20 de Junho de 1998, Mosteiro de Alcobaça. Actas. I. Lisboa: Ministério da Cultura - Instituto Português do Património Arquitectónico, 2000,p. 27-72, indica-o como terceiro ou quarto abade deste importante mosteiro e coloca o seu abaciado entre 1175-1191.

${ }^{12}$ Estes, se apenas contemplarmos os vivos, ao tempo, pois que se sabe que, por então, se contavam dois já falecidos, os infantes Constança e Henrique. 
Assim, pode afirmar-se que o primeiro testamento do rei D. Sancho I surgiu em circunstâncias próprias, onde tiveram peso bastante a "juventude" do reino, a ausência de uma prática suficientemente $\operatorname{arreigada}^{13}$, que consagrasse, na realidade, a sucessão hereditária segundo a linha varonil (embora o documento aponte para a aceitação deste princípio no reino), e alguma apreensão pelo facto de o rei não ter, por esse tempo, nenhum filho (ou filha) de maior idade.

2.2.1. A edição dos documentos de D. Sancho I consagrou a ideia de que o primeiro testamento foi seguido por um codicilo, espécie de complemento ${ }^{14}$.

A análise dos elementos extrínsecos do documento deixa, porém, abertura a outra interpretação. Tendo em conta que testamento e codicilo são oriundos de um mesmo cartório, o da Sé de Viseu (núcleo onde ainda hoje se encontram, no Arquivo Nacional), bem como se apresentam como partes de um mesmo documento (partido por $\mathrm{ABC}$ ), já tivemos ocasião de propor que se trata de um único e mesmo documento, com duas partes distintas, cada uma em seu lugar próprio do suporte pergamináceo que o contém ${ }^{15}$. Também a sua análise intrínseca concorre à mesma ideia. Na sua primeira parte, tradicionalmente entendida como o testamento propriamente dito, após importantes considerações que, a nosso ver, ajudam à justificação do documento e das suas cláusulas, são tratados os problemas do reino e dos filhos do rei enquanto infantes de Portugal e seus herdeiros. Na segunda parte, aquela tradicionalmente chamada de codicilo, avultam as questões ligadas à partilha da sua pecunia, isto é, da distribuição da sua fortuna pelos seus vários filhos, amigos, servidores e instituições religiosas do reino, algumas afigurando-se de sua maior predilecção.

Atentemos, pois, no conteúdo do documento e nas leituras possíveis, de carácter político, que elas permitem, e que se encontram, quase em exclusivo, na primeira parte ${ }^{16}$.

Como ideia primeira, salientemos a preocupação do rei com a sua eventual morte ou infortúnio que impedisse a liberdade de seu corpo e o futuro do reino, o que se apresenta bem concorde à conjuntura proposta para a sua realização.

${ }^{13} \mathrm{O}$ que não poderia mesmo acontecer, dada a juventude do reino, ressalvados, contudo, os sinais da sua aceitação e da sua expressão, no reinado de D. Afonso Henriques, relativamente a seu filho e sucessor, como já frisámos.

${ }^{14}$ Rui de Azevedo, P. Avelino de Jesus da Costa e Marcelino Rodrigues Pereira, Documentos de D. Sancho I (1174-1211), Coimbra, Instituto Nacional de Investigação Científica, Centro de História da Sociedade e da Cultura da Universidade de Coimbra, 1979, p. 49-50, doc. n. ${ }^{\circ} 31$.

${ }^{15}$ Maria Alegria Marques e João Soalheiro, ob. cit., p. 309.

${ }^{16}$ Deste modo, deixamos de lado a análise comum deste tipo de documentos, remetendo, no caso, para a nossa obra A corte dos primeiros reis de Portugal..., p. 308-321. 
Nesse cenário, o voto que o rei deixava expresso era de que todos os seus mais próximos e o seu reino permanecessem em paz e tranquilidade, o que indicia também, e desde logo, um dos pressupostos da governação régia, a manutenção da paz no reino.

Seguem-se-lhe as verdadeiras cláusulas dispositivas, onde avulta a questão da sucessão, aliás patente em duas passagens do documento. Ficava claramente estabelecida a ordem agnática no acesso ao trono. Ao rei Sancho sucederia o filho Afonso, na sua falta ou ausência, o filho Pedro e, depois, nas mesmas circunstâncias, o infante D. Fernando. A disposição era completada por outra passagem que determinava o acesso ao trono das filhas nascidas, Teresa e Sancha, por esta ordem de nascimento, e na absoluta ausência de qualquer filho varão ou seu herdeiro. Considerando a sucessão na família, D. Sancho I conformava-se plenamente ao disposto na bula Manifestis probatum, de Alexandre III, que, além de ter reconhecido Portugal como reino e Afonso Henriques como rei, havia admitido uma nova casa reinante, ao declarar que a terra de Portugal se transmitiria aos herdeiros de Afonso Henriques ${ }^{17}$.

É também nesta primeira parte, aquela que, recordamos, se reveste de maior interesse sob o ponto de vista político, que se acham algumas passagens importantes sobre o pensamento do rei D. Sancho I acerca do papel de sua esposa, a rainha D. Dulce, nas preocupações que sentia e no protagonismo que lhe exigia, no caso de sobrevir algum daqueles perigos de cujo temor o testamento dá conta.

Como marido e como pai, não podem estranhar-se as determinações acerca do futuro de sua esposa e de suas filhas, em caso de sua morte ou prisão. Mas como rei que também era, entendia por bem que elas e os seus bens se acolhessem à protecção de um de cinco castelos que tinha por tão fiéis, que as receberiam como se ele próprio aí se deslocasse, em pessoa. Eram eles os de Alenquer, Montemor, Viseu, Guimarães e o de Santa Maria. Certamente porque este último era o que mais garantias lhe dava, era a ele que mandava que elas se acolhessem, preferencialmente, "se até ele pudessem viajar em segurança" ${ }^{18}$. Nesse caso, e na situação de insegurança e hipotética perturbação,

${ }^{17}$ Ver Maria Alegria Fernandes Marques, “A bula Manifestis probatum. Ecos, textos e contextos", já citado.

${ }^{18}$ Seria bem interessante poder saber-se quem era o tenente deste castelo, pois seria chave para a compreensão de alguns factos menos claros do início do reinado de D. Sancho I. Todavia, nas obras sobre a Feira ou a Terra de Santa Maria, nada se acha que nos elucide acerca do seu governo, neste momento, ou próximo; cfr. José Mattoso, Luís Krus, Amélia Andrade, O castelo e a Feira. A Terra de Santa Maria nos séculos XI a XIII. Lisboa, Estampa, 1989; A. de Almeida Fernandes, Faria e não Feira (1127-1128). Guimarães, Sociedade Martins Sarmento, 1991; 
os restantes castelos deveriam ingressar no poder ("redeuntibus [...] in ius et hominium") do filho que tivesse o reino, excepto o de Montemor, que ele doava, na circunstância, a sua filha mais velha, $\mathrm{D}$. Teresa.

Ainda em resposta à mesma preocupação com sua esposa e filhas, determinava os rendimentos que haviam de ficar a cada uma delas. À rainha (a figura que agora nos importa) caberiam as rendas de Alenquer, das terras do Vouga e de Santa Maria e ainda os rendimentos do Porto, à excepção dos relacionados com a actividade do comércio fluvial ou marítimo que aí já se processaria, e que ficariam ao filho que herdasse o reino. Segue-se a enumeração dos bens que deixava a cada uma de suas filhas ${ }^{19}$, bem como as condições a que ficavam sujeitos se alguma delas casasse, morresse ou saísse do reino ${ }^{20}$, cláusulas que procuravam garantir a indivisibilidade e inalienabilidade do território do reino. Uma vez mais por questões de segurança, rogava ao filho que herdasse o reino que confirmasse e conservasse firme este pacto estabelecido com suas filhas, irmãs desse seu herdeiro.

Nas lutas que se pressentem entre o homem e o rei, e no mesmo sentido de acautelar o estado futuro da rainha e de o tornar uma obrigação do seu herdeiro, tal como de comprometer este com um bom governo do reino, fazia registar uma cláusula que determinava as condições segundo as quais seu filho e herdeiro seria digno de alancar a sua bênção e a de sua mulher, mãe do infante herdeiro. Na sua qualidade de rainha, sempre o seu sucessor a deveria honrar e, do que ele legava a seu herdeiro (e que era o reino), nunca poderia diminuir nada, antes o devia acrescentar e aumentar, mesmo com bens seus.

Numa última cláusula de salvaguarda, acrescentava que aqueles tais que tivessem o seu filho herdeiro sob tutela não poderiam tocar nas quantias de

José Mattoso, Luís Krus, Amélia Andrade, A Terra de Santa Maria no século XIII. Problemas e Documentos. S.1, Comissão de Vigilância do castelo de Santa Maria da Feira, 1993; A. de Almeida Fernandes, A “arquimanha” Feirense de José Mattoso \& C. ${ }^{a}$ Ild. ${ }^{a}$ (Crítica e Polémica). Viseu, Ed. do Autor, 1994.

${ }^{19}$ Por sua vez, às filhas ficavam os bens seguintes: a Teresa, "filia maior", isto é, mais velha, ficava o castelo de Montemor (talvez a exemplo da doação dessa praça que seu pai havia feito, em tempo, a sua irmã Teresa; cfr. Maria Alegria Marques e João Soalheiro, ob. cit., p. 235) e Cabanões (c. Ovar). Esta cláusula garante que o testamento é anterior a 1191, ano do casamento de D. Teresa com o rei de Leão, Afonso IX). À infanta D. Sancha, "filia minor", ficavam as herdades de Bouças (c. Matosinhos), Vila do Conde e Fão (c. Vila do Conde).

${ }^{20}$ Se alguma faltasse, por morte, a outra herdar-lhe-ia os bens; se saísse do reino e regressasse, a outra restituir-lhos-ia; se acontecesse esta morrer ou as duas saírem do reino, teria os bens o filho que reinasse, na condição de lhos devolver, se, de acordo com a hipótese, ela ou ambas regressassem ao reino. 
dinheiro, das torres de Coimbra e de Évora que lhe deixava; antes as deveriam conservar até que ele fosse adulto e estivesse na idade da razão.

Esta determinação é seguida de uma outra, que estipulava que esses mesmos, "no entretanto, defendam o reino com os rendimentos das terras", cláusula que nos parece bem sugestiva, pois indicava aos tutores de um rei criança que o governo do reino se deveria fazer com os rendimentos do próprio reino. É uma cláusula bem interessante, pois revela a visão clara, de que o rei dava mostras, do que eram os bens do reino e os seus próprios, a sua pecunia. Os primeiros eram bens a que o rei destinava fins próprios do reino, enquanto os segundos, como seus próprios, e na sua condição de pai, distribuía como entendia aos filhos, para seu uso e fruição, livres de determinações e encargos.

Por seu turno, a segunda parte desse mesmo documento que encerra o primeiro testamento do rei D. Sancho I (tradicionalmente considerada como codicilo), é o lugar onde se acham os seus bens pessoais e os respectivos destinatários ${ }^{21}$. De interesse mais vasto e com sentido político, acham-se aqui nomeados os seus testamenteiros (entre os quais, a rainha), elemento que destacamos pelo interesse que podia ter ao efectivo valor do documento ${ }^{22}$.

3. Todas as disposições que acabamos de apresentar se mostram com interesse ao reino de Portugal, tanto mais quanto se apresentava numa fase bem primeva de afirmação. Podemos mesmo considerar que em matéria de instituições e de procedimentos, seria mesmo um tempo de busca de modelos e de afirmação de processos.

Assim, e quanto à sucessão, pedra angular da sobrevivência do reino, ficava clara a ideia de sucessão varonil por linha de primogenitura, ao mesmo tempo que ficava afirmada a inalienabilidade e a indivisibilidade do reino.

Mas qual o papel reservado à rainha, num tempo de tão necessária afirmação do reino e num momento de tantos receios do rei, mesmo aquele de poder deixar um filho menor?

No testamento do rei D. Sancho I ela avulta no importante lugar de testamenteira de seu marido, ao lado de personalidades como o bispo de Viseu, D. João, o abade de Alcobaça, o prior de Santa Cruz, o conde D. Mendo

${ }^{21}$ Dos quais salientamos aqueles que destina aos filhos: ao filho, a sua loriga, lorigões, joelheiras, elmo e espada; às filhas, jovens donzelas, legava rocins, talvez especiais. É também nesta parte que se encontram os bens de alma e ainda alguns especialmente destinados, como os que legava a amigos ou fiéis servidores, leigos e eclesiásticos, aos pobres, às obras de castelos e ao local que elegia para sua sepultura.

${ }^{22}$ E que reforça a ideia de que, de facto, o dito "testamento" e o codicilo se tratavam de um só e único documento. 
Gonçalves (da Maia), mordomo da cúria, e D. Pedro Afonso, irmão bastardo e alferes do rei D. Sancho $\mathrm{I}^{23}$.

Contudo, no conjunto do documento, ela é considerada, muito mais a mãe de infantes, onde se contava o futuro rei, obviamente, que uma rainha a quem seu marido deixasse o encargo de um claro protagonismo político. De facto, se ele considerava a possibilidade de uma regência, apenas expressava que ela seria constituída pelos tutores que tivessem seu filho herdeiro sob tutela, sem nenhuma indicação acerca desse conjunto de personalidades, nem, muito menos, da possível participação da rainha. Por outro lado, se se entender que o papel dos testamenteiros ia além do cumprimento das vontades materiais do rei, para abarcar as determinações de carácter político, então teremos de conceder um papel de maior relevo à rainha de Portugal, presuntiva viúva do seu segundo rei. Mas cremos que, em bom rigor, isto fica por demonstrar. E, nesse caso, seria reduzido o papel da hipotética viúva do rei D. Sancho I.

\section{D. Afonso II}

Colocada de lado a generosidade do terceiro rei de Portugal, D. Afonso II, em matéria de testamentos ${ }^{24}$, centremo-nos apenas nos dois primeiros, pois são aqueles que contêm matéria que nos importa.

Era ainda relativamente jovem (teria cerca de 28 anos) ${ }^{25}$ quando fez lavrar o seu primeiro testamento (27.06.1214), ao qual se seguiria um segundo, volvidos que eram pouco mais de uns escassos três anos (28.01.1218).

Se não é possível afirmar, com absoluta segurança, que na base dessa repetição estava a doença que, desde cedo, acompanhou a vida deste infante de

${ }^{23}$ Filho de D. Afonso Henriques e Elvira Gualter. Ao tempo, contava já com uma brilhante carreira na cúria régia, nomeadamente como alferes de seu irmão, enquanto infante e já rei (1181-1192), e participação na solução das arras de sua sobrinha, D. Teresa Sanches, após a dissolução do seu casamento com Afonso IX de Leão (Zamora? Maio-Junho de 1194). Cfr. Maria Alegria Marques e João Soalheiro, ob. cit., p. 64, 70, 245.

${ }^{24}$ De facto, D. Afonso II fez redigir três testamentos, respectivamente em 1214, 1218 e 1220. As suas versões podem ler-se em Maria Teresa Nobre Veloso, D. Afonso II. Relações de Portugal com a Santa Sé durante o seu reinado. Coimbra, Arquivo da Universidade de Coimbra, p. 277-282, docs. n. ${ }^{\circ} 1^{\mathrm{a}}$ e $1 \mathrm{~b}$. Permitimo-nos chamar a atenção para a importância do primeiro destes documentos na história da cultura portuguesa, particularmente da língua portuguesa, por ser considerado o mais antigo documento escrito em português e provido de data; cfr. Avelino de Jesus da Costa, Os mais antigos documentos escritos em português. Revisão de um problema histórico-linguístico. Coimbra, Separata da Revista Portuguesa de História vol. XVII, Coimbra, 1979.

${ }^{25}$ Pois que terá nascido em 23 de Abril de 1186. 
Portugal, depois rei, conhecido esse seu estado, a hipótese ganha mais força, até porque a questão da sucessão tem um lugar importante na economia do seu documento testamentário. Na verdade, nesse ano de 1214 (Junho, 27) o rei de Portugal apenas tinha dois herdeiros, ambos menores, e apenas um varão ${ }^{26}$. A sucessão era, pois, matéria que convinha acautelar.

De facto, não parece longe desta lógica a análise do texto do primeiro testamento de D. Afonso II. Com efeito, pode dizer-se que são reduzidas as matérias nele contidas: questões do reino, de sucessão e de tutela de seu herdeiro, e problemas de bens, partição meeira entre si e a rainha ${ }^{27}$, e do destino da parte que lhe ficasse, que reservava, sobretudo, a bens de alma.

Sobre a sua sucessão, a matéria em causa no momento, importa reter a determinação acerca da ordem sucessória e da tutela do filho mais velho, se ainda não fosse de idade de robora.

Acerca da primeira (ordem sucessória), verifica-se a manutenção das linhas traçadas por seu pai, com a afirmação da linha varonil, segundo a primogenitura, e o consequente afastamento das mulheres, apenas chamadas em caso extremo.

Sobre a segunda, ficava determinado que a tutela de seu herdeiro menor competiria à rainha. Bem como a ela e aos seus vassalos ficaria o governo do reino. Ficava, assim, claramente estabelecida a regência, com a participação da rainha.

Pouco tempo depois, uns três anos e alguns meses, sem razões conhecidas, D. Afonso II fez escrever novo texto testamentário, reelaboração daquele primeiro de anos atrás, como se disse. Tal como no primeiro, lá se encontram as mesmas preocupações com a sua sucessão e o seu reino, com a reafirmação das condições já conhecidas sobre a tutela de seu herdeiro e do seu reino, se viesse a ser necessária, bem como acerca da regência que houvesse de instituir-se no reino.

4. Apesar de tantas preocupações e cautelas, nenhum destes testamentos teve efectivação, pois que os seus autores sobreviveram a suas esposas.

${ }^{26}$ Tratava-se do infante D. Sancho, futuro rei D. Sancho II de Portugal, e da infanta D. Leonor, futura rainha da Dinamarca, por casamento com o rei Valdemar III da Dinamarca, em 1229.

${ }^{27}$ Cláusula que se encontra também no primeiro testamento da rainha sua esposa, desse mesmo ano de 1214 ( 15 de Junho) e que cremos apontar muito mais para uma norma do que para um simples acaso, muito menos uma qualquer prova de afecto recíproco, até porque somos de opinião de que as relações deste régio casal não primariam pela afectividade entre os cônjuges (cfr. Maria Alegria Marques e João Soalheiro, ob. cit., p. 329-330). 
Mas eles deixam bem patente como a primeira das suas preocupações era a sucessão no trono, garantia da segurança do reino e da sua consolidação, a par da manutenção da sua própria família como estirpe reinante.

Quanto às rainhas, se é certo que a sua função principal era dar um herdeiro ao rei, de preferência varão - facto cumprido em qualquer dos casos e verificado por ocasião da realização dos documentos em análise -, também é sabido que não lhe ficava vedado um lugar e um papel junto do rei, seu marido, na administração do reino, a começar pelo conselho ao seu senhor e rei, na prossecução do bom governo e estabilidade do reino. E sobre isto, também os testamentos dos monarcas portugueses nada deixam adiantar.

Como já afirmámos, apenas D. Dulce logrou o lugar de testamenteira de seu marido, mas tal the foi cometido enquanto esposa e não enquanto rainha. Por sua vez, D. Urraca, mulher de D. Afonso II, nem isso logrou. Se estamos convicta de que não foram das melhores as relações deste régio casal ${ }^{28}$, também não temos como demonstrar se esse tipo de relacionamento vinha de tão longe, a ponto de poder ficar, ou não, vertido no testamento real.

Do mesmo modo, as recomendações que o rei D. Sancho I encarregava a seu filho herdeiro relativamente a D. Dulce, no final do seu primeiro testamento, relevavam da sua condição primeira de mãe e não de rainha. Não nos parece que o pouco que fica dito acerca dos encargos que ficavam à rainha $\mathrm{D}$. Dulce seja suficiente à caracterização de um papel político da rainha de Portugal.

Era da sua condição real o que o rei determinava quanto às questões de segurança de sua esposa (e filhas). Em rigor, e por contraste com o testamento de seu filho e herdeiro, nada é dito acerca do governo do reino, embora, ao tempo, esse mesmo filho herdeiro fosse ainda criança. Talvez que, no fundo da alma, o rei tivesse a secreta esperança de que o documento seria apenas um pró-forma e, por isso, omitisse o que pensava ou desejava em caso de morte; nesse cenário, protelava definições, deixando ao encargo de sua esposa e dos seus fiéis a solução de tão problemática situação.

Já no caso de D. Afonso II, desde cedo que o rei deixou claramente expresso o seu pensamento acerca do modo como se efectuaria o governo e qual o papel da rainha, em caso da sua falta, por morte, e da menoridade de seu filho herdeiro. Fê-lo registar nos dois primeiros testamentos, o de 1214 e o de 1218 , os que foram elaborados em tempo em que a rainha poderia sobreviver ao rei. Em ambos, o problema se colocava do mesmo modo. Como mãe, era equacionada a possibilidade de D. Urraca ficar com o papel de tutora

\footnotetext{
${ }^{28}$ Maria Alegria Marques e João Soalheiro, ob. cit., p. 332.
} 
do filho(a) herdeiro(a); como rainha, devia participar na solução que fosse encontrada, com seus vassalos, para o governo do reino, até que o herdeiro tivesse robora, isto é, estivesse em idade de assumir o poder ${ }^{29}$.

Apesar de tudo, não nos parecem muito diferentes as soluções propostas pelo segundo e pelo terceiro monarcas da casa real portuguesa, notando-se, isso sim, alguma evolução na reflexão acerca do lugar da rainha, ou, pelo menos, a explicitação acerca da matéria, em vista do que já deixámos expresso ${ }^{30}$.

Ambos os reis, pai e filho, fizeram dos seus testamentos o veículo de deixarem à posteridade a expressão dos seus desejos e determinações acerca do que pensavam e desejavam para o reino, após a sua morte, e do modo como concebiam o papel de suas esposas. Contudo, enquanto elas são claramente expressas no testamento de D. Afonso II, apenas as vislumbramos intuídas no de D. Sancho I.

De todo o modo, fica-nos a dúvida da sua realização prática, pois que nenhum deles teve efectivação, pela morte das respectivas rainhas em tempo anterior à dos reis, seus maridos. Igualmente nada deixam entrever acerca da capacidade política dessas mulheres que, de longe, vieram para serem membros activos da família real portuguesa ${ }^{31}$.

5. Em tempos de consolidação do reino, quando ainda não se vislumbrava uma teorização das práticas políticas, pelo menos em Portugal, os testamentos dos primeiros reis reflectem o pensamento que as enformava, pelo menos no que diz respeito à sucessão do trono ${ }^{32}$. Por isso, eles assumem um importante

${ }^{29}$ Como se conclui, em ambos os casos, a regência liga-se à menoridade do titular da coroa. Sobre a justificação desse instituto jurídico, ver Martim de Albuquerque, As regências na história do Direito Público e das ideias políticas em Portugal, Lisboa: s. e., 1973, p. 203.

${ }^{30}$ Se se poderá considerar que a ausência desse papel no testamento do rei D. Sancho I poderia ser suprida por determinações orais, o que é facto é que, ao olhar do historiador do nosso tempo e à teorização das práticas, ressaltam apenas as resoluções escritas. E sempre se podem confrontar as determinações do rei D. Sancho I com as de seu filho e sucessor.

${ }^{31}$ Recorde-se que D. Dulce era aragonesa e D. Urraca castelhana. Sobre estas figuras ver, respectivamente, Nuno Pizarro Dias, "Dulce de Aragão e Barcelona" e Bernardo Sá-Nogueira, "Urraca de Castela", in As primeiras rainhas de Portugal. Mafalda de Mouriana. Dulce de Barcelona e Aragão. Urraca de Castela. Mecia Lopes de Haro. Beatriz Afonso. Lisboa, Círculo de Leitores, 2012, p. 107-210 e 211-296); acerca da primeira tem interesse, também, Maria Alegria Marques, D. Dulce. Rainha fecunda. Matosinhos, Quid Novi, 2011.

${ }^{32}$ Que assim era, ressalta ainda de uma passagem dos testamentos de D. Afonso II, em que se justifica o acto precisamente para que sua mulher, seus filhos, seu reino e seus vassalos "sten en paz e en folgancia", para usarmos a expressão do primeiro testamento. Na mesma linha de preocupação com o reino se poderá entender a cláusula de encomendação do cumprimento do testamento ao papa. Tal papel surge reconhecido por exemplo em J. J. Lopes Praça, Direito 
papel no pensamento político, ao tempo ${ }^{33}$. E, quanto a isso, por confronto, os testamentos de D. Sancho I e os de D. Afonso II que foram lavrados enquanto se poderia prever a situação de regência no reino deixam pressentir alguma evolução, ou, pelo menos, clarificação acerca da figura da regência e da participação das rainhas viúvas nos negócios do reino ${ }^{34}$.

Ao mesmo tempo, projectam luz sobre o papel das rainhas, fazendo delas, pelo menos em potência, elementos bem mais importantes e activos que a maioria das vezes se supõe, reduzidas que são, as mais das vezes, ao seu papel reprodutor e a peças-chave da política do seu tempo e dos reinos de que provinham $^{35}$.

Contudo, e como é sabido, os documentos em que estas ideias ficaram expressas não tiveram execução. Daí, não ter merecido a devida atenção a figura

Constitucional Português. I, Coimbra: Imprensa da Universidade, 1893, p. XIX: "De facto, nos testamentos dos nossos reis se regulava a ordem da sucessão do reino, ou por não ser de direito escrito, e somente de direito consuetudinário, ou também porque prevalecesse a ideia de que o reino era património do monarca podendo regular a sucessão". Outros autores dão também lugar de relevo aos testamentos régios. Ver, por exemplo, Ângelo Pereira, As regências da monarquia portuguesa. Lisboa: s. ed., 1942; Marcelo Caetano, História do direito português [1140-1495]. 2. ${ }^{a}$ ed., Lisboa: ed. Verbo, 1985, p. 211-212; Martim de Albuquerque, ob. cit., p. 204-205, notas $5,6,7$.

${ }^{33}$ Apesar dos exemplos dos autores citados na nota anterior, o que se conclui é que eles valorizam apenas os testamentos régios que tiveram efectiva validade e não todos aqueles que os reis fizeram lavrar. Cfr. J. J. Lopes Praça, ob. cit., p. 6-7; Ângelo Pereira, ob. cit., p. 9, nota (3).

${ }^{34}$ Em claríssima oposição com o que sucederia com o caso de Branca de Castela, em França, em 1227, na sequência da morte de Luís VIII, seu marido, o qual nem no seu testamento nem na declaração solene que fez perante os grandes do seu reino, à volta do seu leito de morte, em 3 de Novembro de 1226, em Montpensier, indicou quem desejaria para o exercício da regência do seu reino, após a morte que já tinha por eminente. A posição de destaque, no reino, da rainha Branca de Castela (curiosamente, uma irmã da rainha Urraca de Portugal, como é sabido), já patente nos funerais de seu marido, a 15 de Novembro, em São Dinis de Paris, seria "legalizada por um acto indubitavelmente autêntico, mas insólito", nas palavras de Jacques Le Goff, e que teria consistido numa carta aberta do arcebispo de Sens e dos bispos de Chartres e de Beauvais, informando de que o rei, no seu leito de morte, tinha feito saber que decidia colocar o seu filho e sucessor, o reino e os outros seus filhos sob "le bail et tutelle" da rainha Branca, até que ele alcançasse a idade legal; cfr. Jacques Le Goff, Saint Louis. Paris, Gallimard, 1996, p. 84-85.

${ }^{35}$ Sobre o papel (ou os papéis) das rainhas na Idade Média, ver Joseph F. O’ Callaghan, "The many roles of the medieval queen: some examples from Castille", Theresa Earenfight, "Absent kings: Queens as political partners in the medieval crown of Aragon" e Marta Van Landingham, "Royal portraits: representations of queenship in the thirteenth-century catalan chronicles", in Queenship and political power in Medieval and Early Modern Spain. Burlington, Ashgate, 2005, p. 21-32, 33-51 e 109-119, respectivamente. Entre nós, ver Ana Maria Rodrigues, "Rainhas medievais de Portugal: funções, patrimónios, poderes". Separata de Clio. Revista do Centro de História da Universidade de Lisboa, 16/17, 2008, p. 139-153. 
da regência em mãos de mulheres ${ }^{36}$, cuja prática se aceitava no reino, já por esses tempos ${ }^{37}$, apresentando-se até como uma das vias da sua consolidação, como cremos ter ficado demonstrado.

Recebido em/Text submitted on: 07/01/13

Aceite em/Approved on: 10/05/13

36 Ângelo Pereira, ob. cit., p. 8-9, citando apenas, e em nota (3), o [último] testamento de D. Afonso II, no qual a regência já não pertenceria à rainha, mas aos vassalos. Talvez que a falta de referências à possibilidade de regência das rainhas se deva também ao facto de a primeira regência feminina efectiva, a de Leonor Teles, ter sido tão conturbada e avassaladora, como se sabe. Por sua vez, Martim de Albuquerque, ob. cit., demonstra como foi difícil, em Portugal, a aceitação da regência em mãos femininas. Nem mesmo as biografias dos reis D. Sancho I (D. Sancho I. O filho do fundador, da autoria de Maria João Branco e publicada pelo Círculo de Leitores, Lisboa: 2006) e D. Afonso II (D. Afonso II. Um rei sem tempo, de Hermínia Vilar, publicada pela mesma editora e no mesmo ano da anterior) dão relevo a esta circunstância e a estas leituras, possíveis, dos testamentos régios. Muito menos, as mais recentes, das rainhas D. Dulce e D. Urraca, já citadas supra, nota 31.

${ }^{37}$ O exercício do poder regencial por mulheres, embora esporádico, era uma prática conhecida nas monarquias hispânicas, ao tempo em que se lavraram os documentos em que baseamos esta nossa reflexão. Citem-se os casos das rainhas Toda, de Navarra (por seu irmão García Sánchez I, 926-970); Urraca e Ximena, de Navarra (por seu neto e filho, respectivamente, Sancho Garcez III, o Maior, 1004-1035) e de Berenguela de Castela, irmã da rainha D. Urraca (por seu irmão, Henrique I, 1214-1217). O carácter electivo da monarquia visigótica terá contribuído também para o pouco uso desse procedimento na Península; cfr. António Pereira de Figueiredo, Tentativa Theologica: em que se pretende mostrar... de prover espiritualmente em todos os mais cargos reservados ao Papa. Lisboa, Officina de António Rodrigues Galhardo, 1769, p. 51. Deve notar-se que os casos que citamos, acima, não se podem inserir rigorosamente no mesmo tipo de quadro daqueles que estudamos, pese, embora, a aura que recai sobre as figuras de Toda de Navarra ou, mais recentemente, Berenguela de Castela, pois elas não exerceram o poder em razão de um testamento e em consequência de uma viuvez. Sobre bibliografia acerca destas matérias, de tutela e regência, remetemos para François Olivier-Martin, Études sur les régences. I. Les régences et la majorité des rois sur les Capétiens directs et les premiers Valois (1060-1375). Paris, 1931, louvando-nos em Jacques Le Goff, que considera esta obra "excellent" (cfr.ob.cit., p. 83, n. 3). 